\title{
Design of heat exchanger for the production of synthesis silica
}

DOI:10.36909/jer.ASSEEE.16033

Asep Bayu Dani Nandiyanto ${ }^{1, *}$, Silmi Ridwan Putri ${ }^{1}$, Risti Ragadhita ${ }^{1}$, Rina Maryanti ${ }^{2}$, Teguh Kurniawan $^{3}$

${ }^{1}$ Departemen Kimia, Universitas Pendidikan Indonesia, Bandung, Indonesia.

${ }^{2}$ Departemen Pendidikan Khusus, Universitas Pendidikan Indonesia, Bandung, Indonesia.

${ }^{3}$ Departemen Teknik Kimia, Universitas Sultan Ageng Tirtayasa, Serang, Indonesia.

*Email: nandiyanto@upi.edu; Corresponding Author.

\begin{abstract}
This study aims to analyze and develop a heat exchanger (HE) application for the manufacture of silica nanoparticles synthesis from agricultural waste. This shell and tubetype HE is designed simply, but it still refers to the existing design rules. The design of a shell and tube type HE with one pass shell and tube with turbulence flow. The specifications of the HE apparatus are $1.93 \mathrm{~m}$ in shell length, $0.203 \mathrm{~m}$ in shell diameter, $0.020 \mathrm{~m}$ in inner tube diameter, $0.022 \mathrm{~m}$ in outer tube diameter, and $0.016 \mathrm{~m}$ in thickness. The results showed an effectiveness value of $66.38 \%$ with an impurity factor of 0.01314 . This informed that although the shell and tube-typed HE does not meet the requirements and standards for being set in industrial applications, it can be useful as a learning method regarding the design process, working mechanism, and analyzing the performance of the HE.
\end{abstract}

Keywords: heat exchanger, Performance, Shell and Tube. 


\section{INTRODUCTION}

The heat exchanger (HE) is a heat transfer device that transfers heat energy from one medium to another. A HE is a device that transfers heat from one fluid to another. To reach the ideal thermal in the heat transfer process, two fluids with different temperatures will be separated on the cold side or hot side by a separating medium. The advantage of a HE is that it has high thermal efficiency and is inexpensive. The HE is made up of multiple thin plates that are held together by a frame that runs parallel to the plates. (Ibrahim et al., 2019). HE plays an important role in the operation of many systems, such as power plants, nuclear reactors (Oh et al., 2010), industrial processes (Ma et al., 2016), and as fuel (Magistri et al., 2006 \& Dagdas A., 2007). HE plays a significant part in effective energy use since it is utilized in a variety of applications. HE design development, reliability, and maintenance are continually required to increase whole system performance (Abou Elmaaty et al., 2017). HE has many different types, such as; wire on tube Islamoglu., 2003), crossflow type plate HE (Saman and Alizadeh., 2002), type plate HE (Luan et al., 2008), type ground HE (Saeidi et al., 2018), and plate-fin HE using a new type of vortex generators (Samadifar and Toghraie., 2018).Silica nanoparticles have a wide range of uses, including drug delivery systems, catalysis, biomedicine, biological imaging, chromatography, sensors, liquid shielding, and fillers in composite materials. The shape and size of the silica particles can be altered by altering reaction parameters such as times, temperature, and solvent concentration (Zulfiqar et al., 2016). One of the controllers that can regulate the temperature in the process of making silica nanoparticles is the use of HE. Therefore, the goal of this study is to develop a HE application for the manufacture of silica nanoparticles. This shell and tube-typed HE is designed to be simple but still refers to the existing design rules, making it useful as a learning method regarding the design process, the working mechanism, and the performance of the HE. 


\section{MATERIAL AND METHOD}

\subsection{Manufacturing of silica}

A combination of combustion and acid-based extraction techniques is utilized in the waste extraction process. Figure 1 shows a visual representation of the procedure. The first step is the preparation and carbonization of agricultural waste. After that, the carbonized agricultural waste is cleaned and centrifuged. The carbon washing results were then combined with a $\mathrm{NaOH}$ solution in a polymer batch reactor, and the $\mathrm{NaOH}$ solution was extracted for 2 hours at $70^{\circ} \mathrm{C}$ to yield a silicic acid solution. The temperature during extraction must be kept at a level that allows for optimal silica synthesis. To separate the silicate solution from the carbon residue, the silicic acid solution is centrifuged for 10 minutes. The third step is the nucleation process. After that, phosphoric acid is added to the silicic acid solution extract until the $\mathrm{pH}$ reaches 10 and white solids appear. The resulting white solid is then rinsed with methanol, centrifuged, and dried before being ground into dry silica powder.

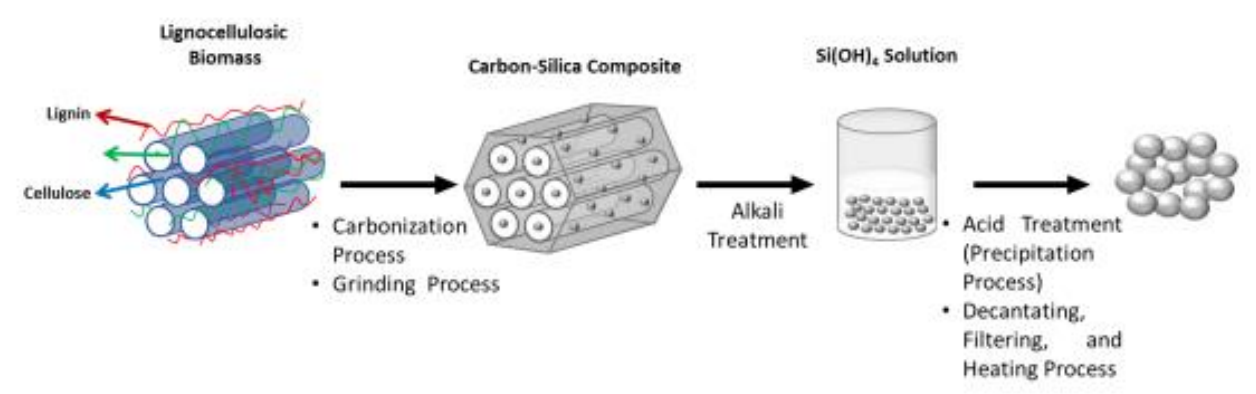

FIGURE 1. Illustration of the steps of fabrication silica from agricultural waste (Nandiyanto, 2020)

\subsection{Mathematical models for Designing HE}

Data processing on the HE is done using Microsoft Excel by triggering the heat transfer that occurs in the HE. Table 1 shows the heat exchange parameters that were calculated. Several data assumptions are used in the process of obtaining the characteristics for a shell and tube HE, including shell length of $1.93 \mathrm{~m}$, shell diameter 
of $0.203 \mathrm{~m}$, inner diameter tube of $0.020 \mathrm{~m}$, outer tube diameter of $0.022 \mathrm{~m}$, and thickness of $0.016 \mathrm{~m}$.

Table 1 HE parameter calculation

\begin{tabular}{|c|c|c|c|c|}
\hline No & Section & Parameter & Equation & $\mathbf{E q}$ \\
\hline \multirow[t]{5}{*}{1} & \multirow[t]{5}{*}{$\begin{array}{l}\text { Basic } \\
\text { parameters }\end{array}$} & $\begin{array}{c}\text { The energy } \\
\text { transferred } \\
\text { (Q) }\end{array}$ & $\begin{array}{l}\qquad Q_{\text {in }}=Q_{\text {out }} \\
\qquad m_{c} \times C p_{c} \times \Delta T_{c}=m_{h} \times C p_{h} \times \Delta T_{h} \\
\mathrm{Q}=\text { the energy transferred }(\mathrm{Wt}) \\
m=\text { the mass flow rate of the fluid }(\mathrm{Kg} / \mathrm{s}) \\
C p=\text { the specific heat } \\
\Delta T=\text { the fluid temperature difference }\left({ }^{\circ} \mathrm{C}\right) \text {. }\end{array}$ & (1) \\
\hline & & $\begin{array}{l}\text { Logarithmic } \\
\text { mean } \\
\text { temperature } \\
\text { differenced } \\
\text { (LMTD) }\end{array}$ & $\begin{array}{l}\qquad L M T D=\frac{\left(T_{h i}-T c_{i}\right)-\left(T_{h o}-T c_{o}\right)}{\ln \frac{\left(T_{h i}-T c_{i}\right)}{\left(T_{h o}-T c_{o}\right)}} \\
T_{h i}=\text { the temperature of the hot fluid inlet } \\
T_{h o}=\text { the temperature of the hot fluid outlet } \\
T c_{i}=\text { the temperature of the cold fluid inlet } \\
T c_{o}=\text { the temperature of the cold fluid outlet } \\
\text { All temperature units are in }{ }^{\circ} \mathrm{C}\end{array}$ & (2) \\
\hline & & $\begin{array}{l}\text { Correction } \\
\text { factor }\end{array}$ & $\begin{array}{c}R=\frac{T_{h i}-T_{h o}}{T_{c o}-T_{c i}} \\
P=\frac{T_{c o}-T_{c i}}{T_{h i}-T_{c i}} \\
F=\frac{\sqrt{R^{2}+1} \ln \left[\frac{1-P}{1-P R}\right]}{(R-1) \ln \left(\frac{2-P\left(R+1-\sqrt{R^{2}+1}\right.}{2-P\left(R+1+\sqrt{R^{2}+1}\right.}\right)}\end{array}$ & $\begin{array}{l}(3) \\
(4) \\
(5)\end{array}$ \\
\hline & & $\begin{array}{c}\text { Heat } \\
\text { Transfer } \\
\text { Field Area } \\
\text { (A) }\end{array}$ & $\begin{array}{l}\qquad A=\frac{Q}{U \times L T M D} \\
Q=\text { the energy transferred }(\mathrm{W}) \\
U=\text { the overall heat transfer coefficient } \\
L M T D=\text { the logarithmic mean temperature } \\
\text { difference. }\end{array}$ & (6) \\
\hline & & $\begin{array}{c}\text { Number of } \\
\text { Tubes }(N)\end{array}$ & $\begin{array}{l}\qquad N=\frac{A}{\pi \times D_{o} \times l} \\
N=\text { the number of tubes } \\
A=\text { the area of the heat transfer area }\left(\mathrm{m}^{2}\right), \\
\pi=\text { the value of } 3.14\end{array}$ & (7) \\
\hline
\end{tabular}




\begin{tabular}{|c|c|c|c|c|}
\hline & & & $\begin{array}{l}D_{o}=\text { the tube diameter }(\mathrm{m}) \\
l=\text { the tube diameter }(\mathrm{m}) .\end{array}$ & \\
\hline & & $\begin{array}{c}\text { Shell } \\
\text { Diameter }\end{array}$ & $\begin{array}{l}\quad D_{s}=0.63\left(\frac{\sqrt{\frac{C L}{C T P} \times\left(\left(A \times(P R)^{2} \times\right.\right.} D_{o}}{l}\right)^{\frac{1}{2}} \\
D_{s}=\text { the shell diameter }(\mathrm{m}) \\
A=\text { the area of the heat transfer area }\left(\mathrm{m}^{2}\right) \\
\mathrm{P}, \mathrm{R}=\text { the correction factor } \\
D_{o}=\text { the tube diameter }(\mathrm{m}) . \\
C T P=\text { the constant }(\text { one tube pass }=0.93 ; \text { two } \\
\text { tube pass }=0.90 ; \text { and three tube pass }=0.85) \\
C L=\text { the constant }\left(C L \text { at } 45 \text { and } 90^{\circ}=1.00 ;\right. \\
\left.C L \text { at } 30^{\circ} \text { and } 60^{\circ}=0.87\right) .\end{array}$ & (8) \\
\hline \multirow[t]{4}{*}{2} & \multirow[t]{4}{*}{ Tube } & $\begin{array}{c}\text { Surface } \\
\text { Area of } \\
\text { Total Heat } \\
\text { Transfer in } \\
\text { Tube }\left(a_{t}\right)\end{array}$ & $\begin{array}{l}\qquad a_{t}=N_{t} \frac{a_{t}^{\prime}}{n} \\
a_{t}=\text { the total heat transfer surface area in the } \\
\text { tube }\left(\mathrm{m}^{2}\right) \\
N_{t}=\text { the number of tubes } \\
a_{t}^{\prime}=\text { the flow area in the tube }\left(\mathrm{m}^{2}\right) \\
n=\text { the number of passes. }\end{array}$ & (9) \\
\hline & & $\begin{array}{c}\text { Mass Flow } \\
\text { Rate of } \\
\text { Water in } \\
\text { Tube }(G t)\end{array}$ & $\begin{array}{l}\qquad G t=\frac{m_{h}}{a_{t}} \\
G t=\text { the mass flow of water in the tube } \\
\left(\mathrm{kg} / \mathrm{m}^{2} \mathrm{~s}\right) \\
m_{h}=\text { the mass flow rate of the hot fluid } \\
(\mathrm{Kg} / \mathrm{s}) \\
a_{t}=\text { the flow area tube }\left(\mathrm{m}^{2}\right.\end{array}$ & $\begin{array}{l}(10) \\
\end{array}$ \\
\hline & & $\begin{array}{c}\text { Reynold } \\
\text { number } \\
(R e, t)\end{array}$ & $\begin{array}{l}\qquad R e_{t}=\frac{d i_{t} \times G t}{\mu} \\
R e_{t}=\text { the Reynolds number in tube } \\
d i_{t}=\text { the inner tube diameter }(\mathrm{m}), \\
G t=\text { the mass flow of water in the tube }\left(\mathrm{m}^{2}\right) \\
\mu=\text { the dynamic viscosity }(\mathrm{kg} / \mathrm{ms}) .\end{array}$ & (11) \\
\hline & & $\begin{array}{c}\text { Prandtl } \\
\text { Number } \\
(P r, t)\end{array}$ & $\begin{array}{l}\qquad \operatorname{Pr}=\left(\frac{C_{p} \times \mu}{K}\right)^{\frac{1}{2}} \\
\operatorname{Pr}=\text { Prandtl number } \\
C p=\text { the specific heat of the fluid in the tube } \\
\mu=\text { the dynamic viscosity of the fluid in the } \\
\text { tube }(\mathrm{Kg} / \mathrm{ms}) \\
K=\text { the thermal conductivity of the tube }\end{array}$ & (12) \\
\hline
\end{tabular}




\begin{tabular}{|c|c|c|c|c|}
\hline & & & material $\left(\mathrm{W} / \mathrm{m}^{\circ} \mathrm{C}\right)$. & \\
\hline & & $\begin{array}{c}\text { Nusselt } \\
\text { number } \\
(N u, t)\end{array}$ & $N u=0.023 \times R e_{t}^{0.6} \times P r^{0.33}$ & (13) \\
\hline & & $\begin{array}{c}\text { Inside } \\
\text { coefficient } \\
\left(h_{i}\right)\end{array}$ & $\begin{array}{l}\qquad h i=\frac{N u \times K}{d_{i}, t} \\
h i=\text { the convection heat transfer coefficient } \\
\text { in the tube }\left(\mathrm{W} / \mathrm{m}^{2}{ }^{\circ} \mathrm{C}\right) \\
K=\text { the thermal conductivity of the material } \\
\left(\mathrm{W} / \mathrm{m}^{\circ} \mathrm{C}\right) \\
d_{i}, t=\text { the inner tube diameter }(\mathrm{m}) .\end{array}$ & (14) \\
\hline \multirow[t]{5}{*}{4} & \multirow[t]{5}{*}{ Shell } & $\begin{array}{c}\text { Shell flow } \\
\text { area }\left(A_{s}\right)\end{array}$ & $\begin{array}{l}\qquad A_{s}=\frac{d_{s} \times C \times B}{P_{t}} \\
\qquad D_{b}=d_{o}\left(\frac{N_{t}}{k_{1}}\right)^{\frac{1}{n_{1}}} \\
d_{s}=\text { the shell diameter }(\mathrm{m}) \\
C=\text { clearance }\left(P_{t}-d_{o}\right) \\
B=\text { the a shell bundle } \\
P_{t}=\text { the tube pitch }\left(1.25 \times d_{o}\right)(\mathrm{m}) .\end{array}$ & $\begin{array}{l}(15) \\
(16)\end{array}$ \\
\hline & & $\begin{array}{l}\text { Mass Flow } \\
\text { Rate of } \\
\text { Water in } \\
\text { Shell }(G s)\end{array}$ & $\begin{array}{l}\qquad G s=\frac{m_{c}}{a_{s}} \\
m_{c}=\text { the mass flow rate of the cold fluid } \\
(\mathrm{kg} / \mathrm{s}) \\
A_{s}=\text { the shell flow area }\left(\mathrm{m}^{2}\right) .\end{array}$ & (17) \\
\hline & & $\begin{array}{c}\text { Equivalent } \\
\text { diameter } \\
\left(d_{e}\right)\end{array}$ & $\begin{aligned} & d_{e}=\frac{4\left(\frac{P t}{2} \times 0.87 P t-\frac{1}{2} \pi \frac{d_{o, t}}{4}\right)}{\frac{1}{2} \pi d_{o, t}} \\
P_{t} & =\text { the tube pitch }\left(1.25 \times d_{o}\right)(\mathrm{m}) \\
\pi & =\text { the value of } 3.14 \\
d_{o, t} & =\text { the tube outside diameter }(\mathrm{m}) .\end{aligned}$ & (18) \\
\hline & & $\begin{array}{c}\text { Reynold } \\
\text { number } \\
(R e, s)\end{array}$ & $\begin{array}{l}\qquad R e_{s}=\frac{d i_{t} \times G t}{\mu} \\
R e_{s}=\text { the Reynold number } \\
d i_{s}=\text { the inner tube diameter }(\mathrm{m}) \\
G s \quad=\text { the mass flow of water in the shell } \\
\left(\mathrm{kg} / \mathrm{m}^{2} \mathrm{~s}\right) \\
\mu \quad=\text { the dynamic viscosity }(\mathrm{Kg} / \mathrm{ms}) .\end{array}$ & (19) \\
\hline & & $\begin{array}{l}\text { Prandtl } \\
\text { Number }\end{array}$ & $\operatorname{Pr}=\left(\frac{C_{p} \times \mu}{K}\right)^{\frac{1}{2}}$ & (19) \\
\hline
\end{tabular}




\begin{tabular}{|c|c|c|c|c|}
\hline & & $(P r, s)$ & $\begin{array}{ll}\operatorname{Pr}_{s} & =\text { the Prandtl number } \\
C p & =\text { the specific heat capacity }\left(\mathrm{kJ} / \mathrm{kg}^{\circ} \mathrm{C}\right) \\
\mu & =\text { the dynamic fluid viscosity }(\mathrm{Kg} / \mathrm{ms}) \\
K & =\text { the thermal conductivity }\left(\mathrm{W} / \mathrm{m}^{\circ} \mathrm{C}\right)\end{array}$ & \\
\hline & & $\begin{array}{c}\text { Nusselt } \\
\text { number } \\
(N u, s)\end{array}$ & $\begin{array}{ll} & N u_{s}=0.023 \times \operatorname{Re}_{s}^{0.6} \times \operatorname{Pr}^{0.33} \\
R e_{s} & =\text { the Reynold number } \\
\operatorname{Pr} & =\text { the Prandtl number }\end{array}$ & (20) \\
\hline & & $\begin{array}{l}\text { Convection } \\
\text { Heat } \\
\text { Transfer } \\
\text { Coefficient } \\
\quad(h o)\end{array}$ & $\begin{array}{l}\qquad h o=\frac{N u \times K}{d_{e}} \\
h o \quad=\text { the convection heat transfer } \\
\text { coefficient }\left(\mathrm{W} / \mathrm{m}^{2} .{ }^{\circ} \mathrm{C}\right) \\
K \quad=\text { the thermal conductivity }\left(\mathrm{W} / \mathrm{m} .{ }^{\circ} \mathrm{C}\right) \\
d_{e}=\text { the equivalent diameter }(\mathrm{m}) .\end{array}$ & (21) \\
\hline 5. & $\begin{array}{l}\text { Shell and } \\
\text { Tube }\end{array}$ & $\begin{array}{c}\text { Actual } \\
\text { Overall } \\
\text { Heat } \\
\text { Transfer } \\
\text { Coefficient } \\
\quad\left(U_{a c t}\right)\end{array}$ & $\begin{array}{l}\qquad U_{a c t}=\frac{1}{\frac{1}{h_{i}}+\frac{\Delta r}{k}+\frac{1}{h_{o}}} \\
h i \quad=\text { the inside heat transfer coefficient } \\
\left(\mathrm{W} / \mathrm{m}^{2} .{ }^{\circ} \mathrm{C}\right) \\
h o \quad=\text { the outside heat transfer coefficient } \\
\left(\mathrm{W} / \mathrm{m}^{2} .{ }^{\circ} \mathrm{C}\right) \text {, } \\
\begin{array}{l}\Delta r \quad=\text { the wall thickness }(\mathrm{m}) \\
K \quad=\text { the thermal conductivity }\left(\mathrm{W} / \mathrm{m} .{ }^{\circ} \mathrm{C}\right)\end{array}\end{array}$ & $(22)$ \\
\hline \multirow[t]{2}{*}{6} & \multirow[t]{2}{*}{ Heat rate } & $\begin{array}{l}\text { Hot Fluid } \\
\text { Rate }\left(C_{h}\right)\end{array}$ & $\begin{array}{l}\qquad C_{h}=m_{h} \cdot C p_{h} \\
C_{h}=\text { the hot fluid rate }\left(\mathrm{W} /{ }^{\circ} \mathrm{C}\right) \\
C p_{h}=\text { the specific heat capacity }\left(\mathrm{J} / \mathrm{kg} .{ }^{\circ} \mathrm{C}\right) \\
m_{h}=\text { the mass flow rate of hot fluid } \\
(\mathrm{kg} / \mathrm{s}) .\end{array}$ & (23) \\
\hline & & $\begin{array}{l}\text { Cold Fluid } \\
\text { Rate }\left(C_{C}\right)\end{array}$ & $\begin{array}{l}\quad C_{C}=m_{c} \cdot C p_{c} \\
C_{c}=\text { the cold fluid rate }\left(\mathrm{W} /{ }^{\circ} \mathrm{C}\right), \\
C p_{h}=\text { the specific heat capacity }\left(\mathrm{J} / \mathrm{kg} .{ }^{\circ} \mathrm{C}\right), \\
m_{c}=\text { the mass flow rate of cold fluid } \\
(\mathrm{kg} / \mathrm{s}) .\end{array}$ & $(24)$ \\
\hline
\end{tabular}




\begin{tabular}{|c|c|c|c|c|}
\hline & & & $\begin{array}{l}T_{h, i}=\text { the temperature of the hot fluid inlet } \\
\left({ }^{\circ} \mathrm{C}\right) \\
T_{c, i}=\text { the temperature of the cold fluid } \\
\text { inlet }\left({ }^{\circ} \mathrm{C}\right) .\end{array}$ & \\
\hline \multirow[t]{3}{*}{7} & \multirow[t]{3}{*}{$\begin{array}{l}\text { Effectivene } \\
\text { ss }\end{array}$} & $\begin{array}{c}\mathrm{HE} \\
\text { Effectivenes } \\
\mathrm{s}(\varepsilon)\end{array}$ & $\begin{array}{c}\varepsilon=\frac{Q a c t}{Q \max } \times 100 \% \\
Q_{a c t}=\text { the actual energy transferred }(\mathrm{W}) \\
Q_{\max }=\text { the maximum heat transfer }(\mathrm{W})\end{array}$ & $(25)$ \\
\hline & & $\begin{array}{c}\text { Number of } \\
\text { Transfer } \\
\text { Unit }(N T U)\end{array}$ & $\begin{array}{l}\qquad N T U=\frac{U \times A}{C_{\min }} \\
\begin{array}{l}U \quad=\text { the overall heat transfer coefficient } \\
\left(\mathrm{W} / \mathrm{m}^{2} \cdot{ }^{\circ} \mathrm{C}\right) \\
A \quad=\text { the heat transfer area }\left(\mathrm{m}^{2}\right) \\
C_{\min }=\text { the minimum heat capacity rate } \\
\left(\mathrm{W} /{ }^{\circ} \mathrm{C}\right) .\end{array}\end{array}$ & $\begin{array}{l}(26) \\
\end{array}$ \\
\hline & & $\begin{array}{c}\text { Fouling } \\
\text { factor }(R f)\end{array}$ & $\begin{array}{l}\qquad R f=\frac{U_{a}-U_{a c t}}{U_{a} \times U_{a c t}} \\
R f \quad=\text { the fouling factor } \\
U_{a}=\text { the overall heat transfer coefficient } \\
\left(\mathrm{W} / \mathrm{m}^{2} \cdot{ }^{\circ} \mathrm{C}\right) \\
U_{a c t}=\text { the actual overall heat transfer } \\
\text { coefficient }\left(\mathrm{W} / \mathrm{m}^{2} \cdot{ }^{\circ} \mathrm{C}\right)\end{array}$ & (27) \\
\hline
\end{tabular}

\section{RESULTS AND DISCUSSION}

The assumptions regarding the fluid characteristics operating on the device are shown in Table 2. Table 3 shows the calculation results of the HE design. Several assumptions were used to derive the HE design specifications, while it developed a shell and tube-type HE. The assumptions used are $1.93 \mathrm{~m}$ in shell length, $0.203 \mathrm{~m}$ in shell diameter, $0.020 \mathrm{~m}$ in inner tube diameter, $0.022 \mathrm{~m}$ in outer tube diameter, and $0.016 \mathrm{~m}$ in thickness.

Table 2 Data of Fluid Properties working on HE

\begin{tabular}{|l|l|l|}
\hline Side & Shell Side & Tube Side \\
\hline Fluida Type & Hot Water $\left(\mathbf{T}_{\mathbf{h}}\right)$ & Cold Water $\left(\mathbf{T}_{\mathbf{c}}\right)$ \\
\hline Iinlet Temperature, $\mathbf{T}_{\text {in }}\left({ }^{\circ} \mathbf{C}\right)$ & 90 & 40 \\
\hline Ooutlet Temperature, $\mathbf{T}_{\text {out }}\left({ }^{\circ} \mathbf{C}\right)$ & 70 & 60 \\
\hline Fluid Flow Rate, $\mathbf{m}(\mathbf{k g} / \mathbf{s})$ & 0.606 & 1 \\
\hline
\end{tabular}




\begin{tabular}{|l|l|l|}
\hline Pressure, $\mathbf{P}(\mathbf{a t m})$ & 1 & 1 \\
\hline Heat Capacity, $\mathbf{C}_{\mathbf{p}}\left(\mathbf{J} / \mathbf{k g}^{\circ} \mathbf{C}\right)$ & 4206 & 4182 \\
\hline Density, $\boldsymbol{\rho}\left(\mathbf{k g} / \mathbf{m}^{3}\right)$ & 1000 & 1000 \\
\hline
\end{tabular}

Table 3 HE specifications based on calculation results

\begin{tabular}{|c|c|c|}
\hline No & Parameter & Results \\
\hline 1 & Initial Heat Transfer Rate $(Q)$ & 84120 Watt \\
\hline 2 & Logarithmic Mean Temperature Difference (LMTD) & $24.85^{\circ} \mathrm{C}$ \\
\hline 3 & $\begin{array}{l}\text { Assumed Overall Fluid Heat Coefficient of Water } \\
\left(U_{a}\right)\end{array}$ & $1000 \mathrm{~W} / \mathrm{m}^{2} .{ }^{\circ} \mathrm{C}$ \\
\hline 4 & Area of Heat Transfer $(A)$ & $3.3846 \mathrm{~m}^{2}$ \\
\hline 5 & Number of Tube $(\mathrm{Nt})$ & 26 \\
\hline 6 & CTP & 0.9 \\
\hline 7 & $C L$ & 0.87 \\
\hline 8 & Total Heat Transfer Surface Area in Tube $\left(a_{t}\right)$ & $0.004551 \mathrm{~m}^{2}$ \\
\hline 9 & Mass Flow Rate of Water Fluid in Tube $(G t)$ & $133.1415 \mathrm{~kg} / \mathrm{m}^{2} . \mathrm{s}$ \\
\hline 10 & Reynold Number in Tube $(\operatorname{Re}, t)$ & 611.5060 \\
\hline 11 & Prandtl Number in Tube $(P r, t)$ & 5.7887 \\
\hline 12 & Nusselt Number in Tube $(\mathrm{Nu}, t)$ & 19.2850 \\
\hline 13 & Convection Heat Transfer Coefficient in the Tube $\left(h_{i}\right)$ & $534.0268 \mathrm{~W} / \mathrm{m}^{2} .{ }^{\circ} \mathrm{C}$ \\
\hline 14 & Bundle Shell $(\mathrm{Db})$ & $0.269 \mathrm{~m}$ \\
\hline 15 & Total Heat Transfer Surface Area in Shell $\left(a_{s}\right)$ & $0.2139 \mathrm{~m}^{2}$ \\
\hline 16 & Mass Flow Rate of Water Fluid in Shell (Gs) & $4.6750 \mathrm{~kg} / \mathrm{m}^{2} . \mathrm{s}$ \\
\hline 17 & Equivalent Diameter $(\mathrm{De})$ & $0.396 \mathrm{~m}$ \\
\hline 18 & Reynold Number in Shell $(R e, t)$ & 6102.6416 \\
\hline 19 & Prandtl Number in Shell $(\mathrm{Pr}, t)$ & 1.3708 \\
\hline 20 & Nusselt Number in Shell $(\mathrm{Nu}, \mathrm{t})$ & 47.6699 \\
\hline 21 & Convection Heat Transfer Coefficient in Shell $\left(h_{o}\right)$ & $81.7340 \mathrm{~W} / \mathrm{m}^{2 \circ} \mathrm{C}$ \\
\hline 22 & Actual Overall Heat Transfer Coefficient $\left(U_{a c t}\right)$ & $70.7058 \mathrm{~W} / \mathrm{m}^{2 \circ} \mathrm{C}$ \\
\hline 23 & Heat Capacity Rate for Hot Fluid $\left(C_{h}\right)$ & $2534.292 \mathrm{~W} /{ }^{\circ} \mathrm{C}$ \\
\hline 24 & Heat Capacity Rate for Cold Fluid $\left(C_{c}\right)$ & $4206 \mathrm{~W} /{ }^{\circ} \mathrm{C}$ \\
\hline 25 & HE Effectiveness $(\varepsilon)$ & $66.3854 \%$ \\
\hline 26 & Number of Transfer Unit $(N T U)$ & 0.0944 \\
\hline 27 & Dirt Factor $(D f)$ & 0.01314 \\
\hline
\end{tabular}

The principle of a HE or HE is to equalize or equalize the difference between the hot fluid's inlet temperature (Thin) and the cold fluid's input temperature (Tc in), with the effects visible at the outlet temperature. The results show the Initial Heat Transfer Rate $(Q)$ in the design of a shell and tube-type HE of $84120 \mathrm{~W}$. In this design, the Reynolds number shows the value of $R e>2300$, so the type of flow that occurs in the shell is turbulent flow. There are various uses for turbulent flow in industrial processes such as heating and cooling. To put it another way, 
most industrial HEs use turbulent flow, which has a larger heat convection coefficient than laminar flow and consequently a better heat transfer rate (Hasanpour et al., 2014).

Based on the calculation results, the effectiveness of the HE is $66.38 \%$. HE effectiveness is the actual heat transfer rate divided by the maximum possible heat transfer rate (San et al., 2012). The resulting effectiveness value, which measures the amount of heat carried, will be high if the temperature differences between the input and output are large. So it can also be interpreted that the effective value of the HE is directly proportional to the magnitude of the temperature difference $\left(\Delta T_{L M T D}\right)$ (Rao et al., 2020).

Other factors that affect the HE's performance include the number and spacing of baffles in the HE's specs. A close baffle distance will increase the effectiveness of the HE as well as a small percentage of baffle cut will increase the effectiveness of the HE (Mohammadi et al., 2020).

When computing the overall heat transfer coefficient, fouling is conventionally considered by using an additional thermal resistance value of Rf or the so-called "fouling factor" or "fouling resistance". The impurity factor responsible for the decrease in the performance of the HE depends on the flow rate. Cutters can reduce overall heat transfer, so an extra surface must be provided to ensure that the required heat transfer is achieved. The standard permissible impurity factor from TEMA for fluid water is $0.0002^{\circ} \mathrm{C} . \mathrm{m}^{2} / \mathrm{W}$, while the value of the impurity factor in this study was $0.01314{ }^{\circ} \mathrm{C} . \mathrm{m}^{2} / \mathrm{W}$. Therefore, the shell and tube-type HE does not meet the requirements and standards. 


\section{CONCLUSION}

Based on the calculations that have been carried out, it can be concluded that the results of the design of a shell and tube-type HE with one pass shell and tube turbulence flow, with specifications of $1.93 \mathrm{~m}$ in shell length, $0.203 \mathrm{~m}$ in shell diameter, $0.020 \mathrm{~m}$ in inner tube diameter, $0.022 \mathrm{~m}$ in outer tube diameter, and $0.016 \mathrm{~m}$ in thickness, has an effectiveness of $66.38 \%$ and an impurity factor of 0.01314 . Therefore, the shell and tube type HE that has been designed does not meet the requirements and standards that have been set.

\section{ACKNOWLEGEMENT}

We would like to thank Universitas Pendidikan Indonesia for supporting this study. We acknowledged RISTEK BRIN (Grant: Penelitian Terapan Unggulan Perguruan Tinggi) and Bangdos Universitas Pendidikan Indonesia.

\section{REFERENCES}

Abou Elmaaty, T. M., Kabeel, A. E., \& Mahgoub, M. 2017. Corrugated plate HE review. Renewable and Sustainable Energy Reviews. 70: 852-860.

AIbrahim, H., Sazali, N., Shah, A. S. M., Karim, M. S. A., Aziz, F., \& Salleh, W. N. W. 2019. A review on factors affecting heat transfer efficiency of nanofluids for application in plate HE. Journal of Advanced Research in Fluid Mechanics and Thermal Sciences. 60(1): 144-154.

Dagdas, A. 2007. HE optimization for geothermal district heating systems: A fuel saving approach. Renewable Energy. 32(6): 1020-1032.

Hasanpour, A., Farhadi, M., \& Sedighi, K. 2014. A review study on twisted tape inserts on turbulent flow HEs: The overall enhancement ratio criteria. International Communications In Heat and Mass Transfer. 55: 53-62.

Islamoglu, Y. 2003. A new approach for the prediction of the heat transfer rate of the wire- 
on-tube type HE-use of an artificial neural network model. Applied Thermal Engineering. 23(2): 243-249.

Luan, Z. J., Zhang, G. M., Tian, M. C., \& Fan, M. X. 2008. Flow resistance and heat transfer characteristics of a new-type plate HE. Journal of Hydrodynamics. 20(4): 524529.

Ma, H., Yin, L., Shen, X., Lu, W., Sun, Y., Zhang, Y., \& Deng, N. 2010.. Experimental study on heat pipe assisted HE used for industrial waste heat recovery. Applied Energy. 169: 177-186.

Magistri, L., Traverso, A., Massardo, A. F., \& Shah, R. K. 2006. HEs for fuel cell and hybrid system applications. 3: 111-118

Mohammadi, M. H., Abbasi, H. R., Yavarinasab, A., \& Pourrahmani, H. 2020. Thermal optimization of shell and tube HE using porous baffles. Applied Thermal Engineering. 170: 115005.

Nandiyanto, A. B. D., Ragadhita, R., \& Istadi, I. 2020. Techno-economic Analysis for the Production of Silica Particles from Agricultural Wastes. Moroccan Journal of Chemistry. 8(4): 8-4.

Oh, C. H., Kim, E. S., \& Patterson, M. 2010. Design option of HE for the next generation nuclear plant. Journal of Engineering for Gas Turbines and Power. 132(3): .

Saeidi, R., Noorollahi, Y., \& Esfahanian, V. 2018. Numerical simulation of a novel spiral type ground $\mathrm{HE}$ for enhancing heat transfer performance of geothermal heat pump. Energy Conversion and Management. 168: 296-307.

Samadifar, M., \& Toghraie, D. 2018. Numerical simulation of heat transfer enhancement in a plate-fin $\mathrm{HE}$ using a new type of vortex generators. Applied Thermal Engineering. 133: 671-681.

Saman, W. Y., \& Alizadeh, S. 2002. An experimental study of a cross-flow type plate HE 
for dehumidification/cooling. Solar Energy. 73(1): 59-71

San, J. Y., Hsu, C. H., \& Chen, S. H. 2012. Heat transfer characteristics of a helical HE. Applied Thermal Engineering. 39: 114-120.

Rao, B. S., Reddy, C.K., Meena, P., \& Kumar, S.K. 2020. Thermal performance of corrugated plate HE using ethylene glycol as test fluid. Journal of Mechanical and Energy Engineering, 44(4): 167-172

Zulfiqar, U., Subhani, T., \& Husain, S. W. 2016. Synthesis and characterization of silica nanoparticles from clay. Journal of Asian Ceramic Societies. 4(1): 91-96. 